\title{
Bexarotene Promotes Cholesterol Efflux and Restricts Apical-to-Basolateral Transport of Amyloid- $\beta$ Peptides in an In Vitro Model of the Human Blood-Brain Barrier
}

\author{
Mélanie Kuntz, Pietra Candela, Julien Saint-Pol, Yordenca Lamartinière, Marie-Christine Boucau, \\ Emmanuel Sevin, Laurence Fenart and Fabien Gosselet* \\ Université d'Artois (UArtois), LBHE, EA2465, Lens, France
}

Handling Associate Editor: Maria Deli

Accepted 3 July 2015

\begin{abstract}
One of the prime features of Alzheimer's disease (AD) is the excessive accumulation of amyloid- $\beta$ (A $\beta$ ) peptides in the brain. Several recent studies suggest that this phenomenon results from the dysregulation of cholesterol homeostasis in the brain and impaired bidirectional $A \beta$ exchange between blood and brain. These mechanisms appear to be closely related and are controlled by the blood-brain barrier (BBB) at the brain microvessel level. In animal models of AD, the anticancer drug bexarotene (a retinoid $\mathrm{X}$ receptor agonist) has been found to restore cognitive functions and decrease the brain amyloid burden by regulating cholesterol homeostasis. However, the drug's therapeutic effect is subject to debate and the exact mechanism of action has not been characterized. Therefore, the objective of this present study was to determine bexarotene's effects on the BBB. Using an in vitro model of the human BBB, we investigated the drug's effects on cholesterol exchange between abluminal and luminal compartments and the apical-to-basolateral transport of $\mathrm{A} \beta$ peptides across the $\mathrm{BBB}$. Our results demonstrated that bexarotene induces the expression of ABCA1 but not ApoE. This upregulation correlates with an increase in ApoE2-, ApoE4-, ApoA-I-, and HDL-mediated cholesterol efflux. Regarding the transport of $A \beta$ peptides, bexarotene increases the expression of $\mathrm{ABCB} 1$, which in turn decreases $\mathrm{A} \beta$ apical-to-basolateral transport. Our results showed that bexarotene not only promotes the cholesterol exchange between the brain and the blood but also decreases the influx of A $\beta$ peptides across BBB, suggesting that bexarotene is a promising drug candidate for the treatment of $\mathrm{AD}$.
\end{abstract}

Keywords: ABCA1, ABCB1, A $\beta$ peptide, bexarotene, blood-brain barrier, cholesterol, RAGE, RXR

\section{INTRODUCTION}

Alzheimer's disease $(\mathrm{AD})$ is a neurodegenerative pathology that affects almost 44 million people around the world. According to the amyloid cascade hypothesis, accumulation of amyloid- $\beta(A \beta)$ peptides in the

\footnotetext{
${ }^{*}$ Correspondence to: Dr. Fabien Gosselet, Université d'Artois, Faculté des Sciences Jean Perrin, Laboratoire de la Barrière HématoEncéphalique, EA 2465, F-62307 Lens cedex, France. Tel.: +33 321 791 751; Fax: +33 321791 736; E-mail: fabien.gosselet@univartois.fr.
}

brain is one of the prime features of $\mathrm{AD}$ [1]. In the brain, these peptides are derived from the cleavage of the amyloid- $\beta$ protein precursor expressed essentially by neurons. The enzymes involved in this process have been identified and it is now clear that their activities are closely linked to the neuronal cholesterol content [2]. Accordingly, it is now acknowledged that $\mathrm{AD}$ is closely associated with lipid metabolism. A close relationship between cholesterol and AD is suggested by the fact that (1) cholesterol is a dietary risk factor in humans [3, 4] and animals [5-7] and (2) the ApoE4 
allele is the most strongly associated genetic factor in AD identified to date [8].

For all these reasons, several current therapeutic approaches for treating $\mathrm{AD}$ patients consist of targeting $A \beta$ peptide metabolism and modulating the brain's cholesterol metabolism and ApoE expression/lipidation. In the brain, ApoE's lipidation status depends on the ATP-binding cassette family subfamily A member 1 transporter (ABCA1), which transfers lipids to ApoE, ApoA-I, and high-density lipoproteins (HDLs) [9, 10]. Several studies have demonstrated that deletion of ABCA1 expression increases the amyloid burden in murine models of AD [11-13], whereas overexpression of the gene decreases amyloid deposition and improves the animals' behavior [14]. Likewise, several natural or synthetic modulators of ABCA1 expression have significant effects on amyloid synthesis, degradation, and clearance from the brain [15, 16]. One of the most promising molecules in this field is bexarotene-a drug that has been approved by the US Food and Drug Administration for the treatment of certain types of cutaneous T-cell lymphoma. In 2012, Cramer et al. elegantly demonstrated that oral administration of this molecule decreased the area and number of $A \beta$ plaques, increased the clearance of $\mathrm{A} \beta$ peptides, stimulated memory (contextual fear conditioning) and olfactory functions, and improved the social behavior (construction nest) of treated AD mice [17]. This effect has been attributed to bexarotene's ability to modulate the expression of ABCA1, ApoE, and other genes involved in lipid metabolism through obligatory heterodimerization of the retinoid X receptors (RXRs) with liver X receptors and peroxisome proliferator-activated receptors [17]. Furthermore, bexarotene induces microglial and astrocyte-mediated clearance of $A \beta$ peptides, although the corresponding cellular and molecular mechanisms have yet to be characterized in detail [17]. Several research groups have tried to reproduce Cramer's initial study in various different AD models, with disparate results [18-23]. Therefore the link between bexarotene, ApoE, ABCA1, and AD could be of potential therapeutic value, although further investigation of the underlying cellular and molecular mechanisms is required [24].

With these considerations in mind, the main objective of the present study was to evaluate the effect of bexarotene on the blood-brain barrier (BBB), which is considered to be of primary importance in $\mathrm{AD}$ [25-27]. This barrier is located at the level of the brain's microvessels and strictly controls the exchange of nutrients and other compounds between the brain and the body [28]. The brain endothelial cells (ECs) composing the BBB express several receptors, enzymes, and transporters that regulate brain homeostasis and composition of the milieu. We and others have demonstrated in vivo, in situ, and in vitro that ABCA1 is the major protagonist in the exchange of cholesterol between the brain and the blood [29-31]. The BBB also participates in the regulation of the brain pool of $A \beta$ peptides in general and the re-entry of these peptides into the brain in particular [32-36]. The receptor for advanced glycation end-products (RAGE, expressed at the EC luminal membrane) is involved in the blood-tobrain transport of $A \beta[32,34]$, whereas $A B C B 1$ and probably $A B C C 1$ restrict $A \beta$ re-entry into the brain [25, 37, 38].

By using an in vitro model of the human BBB that expresses the RXRs (the cells' gene expression profile is available at http://www.ncbi. nlm.nih.gov/geo/query/acc.cgi?acc=GSE45171), we sought to investigate bexarotene's effects on the BBB's ability to exchange cholesterol and $A \beta$ peptides. This model involves culturing hematopoietic stem cells obtained from umbilical cord blood with brain pericytes [39].

Our results demonstrate that bexarotene (1) induces the expression of ABCA1, (2) mediates the efflux of cholesterol toward ApoA-I, ApoE2, ApoE4, and HDL, and (3) increases the expression of ABCB1, which in turn decreases the apical-to-basolateral transport of $A \beta$ peptides.

\section{MATERIALS AND METHODS}

\section{Chemicals}

ApoA-I and HDL were purchased from VWR (Fontenay-sous-Bois, France). ApoE2 and E4 were purchased from Clinisciences (Montrouge, France) and were resuspended in sterile water at a concentration of $1 \mathrm{mg} / \mathrm{mL}$. Bexarotene, Lucifer Yellow (LY), and human serum albumin (HSA) were purchased from Sigma. Bexarotene was dissolved in DMSO (dimethylsulfoxide from Sigma) at concentration of $40 \mathrm{mM}$. $\left[{ }^{3} \mathrm{H}\right]$ cholesterol $(43 \mathrm{Ci} / \mathrm{mmol}),\left[{ }^{14} \mathrm{C}\right]$ sucrose $(630 \mathrm{mCi} / \mathrm{mmol})$, and $\left[{ }^{3} \mathrm{H}\right]$ inulin $(1.25 \mathrm{Ci} / \mathrm{mmol})$ were purchased from PerkinElmer Life and Analytical Sciences (Waltham, MA, USA). Fluorescent amyloid beta-protein (1-40) (human)-Cy5 labeled was purchased from Phoenix Pharmaceuticals (Strasbourg, France). The powder was reconstituted according to the manufacturer's instructions, in order to avoid peptide aggregation. Briefly, the peptide was resuspended 
in $10 \%$ DMSO in buffer and stored at $-20^{\circ} \mathrm{C}$. The ABCB1 inhibitor elacridar was kindly provided by Dr. Stefan Lundquist (AstraZeneca R\&D, Södertälje, Sweden) and resuspended in DMSO.

\section{The human BBB model derived from \\ hematopoietic stem cells}

The human BBB model has previously been described in detail [39]. All the donors of umbilical cord blood samples had given their written, informed consent, in compliance with French legislation. The sample collection was approved by the local investigational review board (Béthune Maternity Hospital, Béthune, France).

\section{Isolation of CD34+ cells}

Briefly, CD34+ cells were isolated from the umbilical cord blood and differentiated into ECs by using a previously published protocol [40]. For this differentiation step, isolated CD34+ cells were cultured in Endothelial Cell Medium (ECM, Sciencell, Carlsbad, CA, USA) supplemented with $20 \%$ (v/v) fetal calf serum (FCS; Life Technologies) and $50 \mathrm{ng} / \mathrm{mL}$ of recombinant human $\mathrm{VEGF}_{165}$ (PeproTech Inc.) on $0.2 \%$ (w/v) gelatin-coated 24-well plates. After 15 to 20 days, ECs can be seen in the culture dish. Cells were then trypsinized and expanded in $0.2 \%(\mathrm{w} / \mathrm{v})$ gelatincoated $100 \mathrm{~mm}$ Petri dishes (BD Corning Falcon) in ECM supplemented with $5 \%(\mathrm{v} / \mathrm{v}) \mathrm{FCS}, 50 \mu \mathrm{g} / \mathrm{mL}$ gentamycin (Biochrom $\mathrm{AG}$ ), and $1 \mathrm{ng} / \mathrm{mL}$ basic fibroblast growth factor (bFGF).

\section{Brain pericyte culture}

To reproduce the $\mathrm{BBB}$, ECs were co-cultured with bovine brain pericytes isolated as described by Vandenhaute et al. [41]. For this co-culture experiment, the brain pericytes were initially seeded on 60-mm gelatin-coated Petri dishes and cultured in Dulbecco's Modified Eagle's Medium (DMEM, Fisher Scientific, Illkirch, France) supplemented with $20 \%$ (v/v) FCS $2 \mathrm{mM}$ L-glutamine, $50 \mu \mathrm{g} / \mathrm{mL}$ gentamycin and $1 \mathrm{ng} / \mathrm{mL}$ bFGF. The cells reached confluence after 2 days. Lastly, $50 \times 10^{3}$ cells were seeded into individual wells of 12-well plates (Corning, NY, USA).

\section{The BBB model}

$\mathrm{CD}^{+}{ }^{+}$ECs growing on gelatin-coated $100 \mathrm{~mm}$ Petri dishes in ECM supplemented with 5\% (v/v) FCS,
$50 \mu \mathrm{g} / \mathrm{mL}$ gentamycin (Biochrom AG) and $1 \mathrm{ng} / \mathrm{mL}$ bFGF were trypsinized and seeded at a density of $8 \times 10^{4}$ cells/insert on Matrigel-coated (BD Biosciences, Le Pont de Claix, France) Transwell inserts (Corning).

After 6 days of co-culture, the ECs acquire the tight junctions and transporters typically observed in brain endothelium and display most of the BBB's in vivo properties for at least 20 days [39]. Hence, the ECs are referred to as brain-like endothelial cells (BLECs) after this point in time. The BLECs' gene expression profile is available at http://www.ncbi. nlm.nih.gov/geo/query/acc.cgi?acc=GSE45171

\section{Endothelial permeability measurements}

The presence of functional tight junctions in BLECs after $24 \mathrm{~h}$ of treatment with different doses $(0-100 \mathrm{nM})$ of bexarotene was checked by calculating the endothelial permeability coefficient $(\mathrm{Pe})$ of two BBB integrity markers (20 $\mu \mathrm{M} \mathrm{LY}$ and $\left[{ }^{14} \mathrm{C}\right]$ sucrose), as previously described [39]. Briefly, prior to the experiments, HEPES-buffered Ringer's solution (RH buffer, pH 7.4, HEPES 5 mM; $\mathrm{NaHCO}_{3} 6 \mathrm{mM}$; $\mathrm{NaCl} 150 \mathrm{mM}$; $\mathrm{KCl} 5.2 \mathrm{mM} ; \mathrm{CaCl}_{2} 2.2 \mathrm{mM} ; \mathrm{MgCl}_{2}+6 \mathrm{H}_{2} \mathrm{O} 1.2 \mathrm{mM}$ ) was added to empty wells of a 12-well plate (Costar). Filter inserts with BLECs were subsequently placed in the wells, which were then filled with solution containing LY or $\left[{ }^{14} \mathrm{C}\right]$ sucrose and placed on an orbital shaker. For the LY experiments, filter inserts were withdrawn from the receiver compartment after 20, 40, and $60 \mathrm{~min}$. Aliquots from the donor solution were taken at the beginning and end of the experiments, and (for LY) the fluorescence was then quantified (with a Synergy $\mathrm{H} 1$ multiplate reader (Biotek); excitation at $432 \mathrm{~nm}$, emission at $538 \mathrm{~nm}$ ).

For sucrose, Pe was calculated after $30 \mathrm{~min}$. Radioactivity was measured in a liquid scintillation counter (Tri-Carb 2100TR).

At least three inserts with cells and three inserts without cells were tested in each permeability measurement, and each experiment was run at least three times.

\section{Immunostaining}

After $24 \mathrm{~h}$ of treatment with $100 \mathrm{nM}$ bexarotene or DMSO, BLECs were washed with pH 7.4 phosphate buffered saline-calcium- and magnesium-free solution (PBS-CMF; $8.0 \mathrm{~g} / \mathrm{L} \mathrm{NaCl}, 0.2 \mathrm{~g} / \mathrm{L} \mathrm{KCl}, 0.2 \mathrm{~g} / \mathrm{L}$, $\mathrm{KH}_{2} \mathrm{PO}_{4}$ et $2.87 \mathrm{~g} / \mathrm{L} \quad \mathrm{Na}_{2} \mathrm{HPO}_{4}-12 \mathrm{H}_{2} \mathrm{O}$ ) once and then fixed in $4 \%$ paraformaldehyde for $10 \mathrm{~min}$ at 
room temperature (RT). After three washes in PBS$\mathrm{CMF}$, filters were cut free from the plastic insert and the cells were rinsed three times in PBS and permeabilized with Triton $\mathrm{X}-100(0.1 \%(\mathrm{w} / \mathrm{v}))$ in PBS-CMF for $10 \mathrm{~min}$ at RT. Following a 30-min incubation in PBS-CMF supplemented with $10 \%$ (v/v) normal goat serum (NGS), cells were incubated for $1 \mathrm{~h}$ with the primary antibody at RT (anti-ZO1 (red) or anti-Occludin (green), Invitrogen, Cergy-Pontoise, France). After 3 washes in PBS-CMF supplemented with $2 \%$ NGS, preparations were incubated with the secondary antibody for $30 \mathrm{~min}$ at RT. Nuclei were stained using Hoechst reagent (blue). Cells were mounted using Mowiol (Sigma-Aldrich) containing 1,4-diazabicyclo[2.2.2] octane (Sigma-Aldrich) as an anti-quenching agent. Images were collected using a Cool SNAP RS Photometrics camera (Leica Microsystems) and processed using Adobe Photoshop software (version 5.5, Adobe Systems, San Jose, CA, USA).

\section{mRNA extraction and PCR analysis}

After $24 \mathrm{~h}$ of treatment with different concentrations of bexarotene, BLECs were rinsed twice with cold PBS $\left(8 \mathrm{~g} / \mathrm{L} \mathrm{NaCl}, 0.2 \mathrm{~g} / \mathrm{L} \mathrm{KCl}, 0.2 \mathrm{~g} / \mathrm{L} \mathrm{KH} \mathrm{KHO}_{4}, 2.87 \mathrm{~g} / \mathrm{L}\right.$ $\mathrm{NA}_{2} \mathrm{HPO}_{4}\left(12 \mathrm{H}_{2} \mathrm{O}\right), \mathrm{pH}$ 7.4) and then lysed with $500 \mu \mathrm{L}$ of RLT lysis buffer (Qiagen). For each condition, three wells were pooled. mRNA was purified using the RNeasy total RNA extraction kit (Qiagen), following the manufacturer's instructions. After this step, the mRNA's purity and concentration were assessed by measuring the absorbance at 260,280 , and $320 \mathrm{~nm}$ using the Take 3 microplate reader protocol (Synergy ${ }^{\mathrm{TM}} \mathrm{H} 1$, Biotek). Only samples with a purity value over 2 were used in experiments.

For each condition, cDNAs were obtained from $0.5 \mu \mathrm{g}$ of mRNA using iScript ${ }^{\mathrm{TM}}$ Reverse Transcription Supermix (BioRad, Marnes-la-Coquette, France), according to the manufacturer's instructions. Realtime PCR experiments were performed using the Sso Fast EvaGreen Master Mix kit (BioRad) and the custom-designed primers listed in Table 1. For each primer, amplification was carried out for 40 cycles with an annealing temperature of $60^{\circ} \mathrm{C}$ in a CFX96 thermocycler (BioRad). The efficiency was calculated for each primer pair (CFX Manager, BioRad). Melting curve analysis was performed after the amplification cycles, in order to check the specificity/purity of each amplification. Gene expression levels were evaluated according to the $\Delta \Delta \mathrm{Ct}$ method and normalized against ACTB and RPLP0 expression.

\section{Protein extraction and analysis}

After 24 h of treatment with bexarotene, BLECs were washed twice in PBS-CMF supplemented with $0.1 \mathrm{~g} / \mathrm{L}$ $\mathrm{CaCl}_{2}$ and $0.1 \mathrm{~g} / \mathrm{L} \mathrm{MgCl}_{2} * 6 \mathrm{H}_{2} \mathrm{O}$ at $37^{\circ} \mathrm{C}$ and then incubated with collagenase $(1 \mathrm{mg} / \mathrm{mL}$ in PBS, SigmaAldrich) for $5 \mathrm{~min}$. Enzymatic activity was quenched by transferring the resulting cell suspension into coculture medium at $37^{\circ} \mathrm{C}$. After an initial centrifugation step ( $800 \mathrm{rpm}$ at $4^{\circ} \mathrm{C}$ for $8 \mathrm{~min}$ ), the supernatant was discarded, and the cells were resuspended in PBS$\mathrm{CMF}$ and centrifuged again. After discarding all of the supernatant, the cell pellets were placed in RIPA lysis buffer supplemented with protease/phosphatase inhibitors (Sigma). Three wells were pooled for each condition. The protein concentration was then measured using the Bradford method (BioRad). Fifteen $\mu \mathrm{g}$ of extract were then electrophoresed on 4-15\% sodium dodecyl sulfate polyacrylamide gel (BioRad) and electrotransferred onto nitrocellulose membranes (GE Healthcare, Saclay, France). After a 90-min incubation in blocking buffer (25 mM Tris- $\mathrm{HCl}$ (pH 8.0), $125 \mathrm{mM}$ $\mathrm{NaCl}, 0.1 \%$ Tween 20 , and $5 \%$ skimmed milk) at $37^{\circ} \mathrm{C}$, membranes were incubated with appropriate primary antibodies overnight at $4{ }^{\circ} \mathrm{C}(($ anti-ABCA $1(1 \mu \mathrm{g} / \mathrm{mL})$, anti-RAGE, $(0.3 \mu \mathrm{g} / \mathrm{mL})$, anti-SCARB1 $(0.4 \mu \mathrm{g} / \mathrm{mL})$, anti-ABCC1 $(1 \mu \mathrm{g} / \mathrm{mL})$, anti-ApoE $(5 \mu \mathrm{g} / \mathrm{mL})$; ABCAM), anti-ABCB1 (0.18 $\mu \mathrm{g} / \mathrm{mL}$; Genetex $)$, anti$\beta$-ACTIN $(0.05 \mu \mathrm{g} / \mathrm{mL})$; Sigma)), rinsed three times with blocking buffer and incubated with appropriate horseradish peroxidase (HRP)-conjugated secondary antibody (Dako) for $1 \mathrm{~h}$ at RT. The HRP was assayed with an enhanced chemiluminescence kit (GE Healthcare) and revealed on chemiluminescence-sensitive films (GE Healthcare). The bands' optical densities were measured using TotalLab TL 100 1D Gel Analysis software (Nonlinear Dynamics, Newcastle, UK). In these experiments, $\beta$-actin and tubulin were used as loading controls.

\section{Cholesterol efflux from BLECs}

First, $\left[{ }^{3} \mathrm{H}\right]$-cholesterol $(0.5 \mu \mathrm{Ci} / \mathrm{mL})$ was incorporated into serum $(20 \% \mathrm{FCS}$, as described above) for $6 \mathrm{~h}$ at $37^{\circ} \mathrm{C}$. This serum was then supplemented with $\mathrm{bFGF}$ $1 \mathrm{ng} / \mathrm{mL}$, glutamine $2 \mathrm{mM}$, and gentamicin $50 \mu \mathrm{g} / \mathrm{mL}$, in order to obtain radiolabeled medium. Cells were then cultured for $36 \mathrm{~h}$ with this medium and then rinsed twice with warm ECM/0.05\% HSA. After this step, the BLECs were incubated in ECM/HSA $0.05 \% / \mathrm{bFGF}$ $1 \mathrm{ng} / \mathrm{mL}$ supplemented (or not) with $100 \mathrm{nM}$ of bexarotene at $37^{\circ} \mathrm{C}, 5 \% \mathrm{CO}_{2}$. After $24 \mathrm{~h}$ of treatment, 
Table 1

DNA primers used to amplify mRNA in human brain-like endothelial cells

\begin{tabular}{|c|c|c|c|c|}
\hline mRNA & Species & $\mathrm{F} / \mathrm{R}$ & Sequences & Accession Number \\
\hline \multirow[t]{2}{*}{$\overline{\mathrm{ABCA} 1}$} & Homo sapiens & $\mathrm{F}$ & $5^{\prime}$-cagtgcttcctgattagcacac-3' & NM_005502 \\
\hline & & $\mathrm{R}$ & $5^{\prime}$-aggctagcgaagatcttgagtg- $3^{\prime}$ & \\
\hline \multirow[t]{2}{*}{ ABCB1 } & Homo sapiens & $\mathrm{F}$ & $5^{\prime}$-gcctggagctggaagacaaatacacaaaa- $3^{\prime}$ & NM_000927 \\
\hline & & $\mathrm{R}$ & $5^{\prime}$-cagacagcagctgacagtccaagaacagga- $3^{\prime}$ & \\
\hline \multirow[t]{2}{*}{$\mathrm{ABCC} 1$} & Homo sapiens & $\mathrm{F}$ & $5^{\prime}$-accaagacgtatcaggtggcc- $3^{\prime}$ & NM_004996 \\
\hline & & $\mathrm{R}$ & $5^{\prime}$-ctgtctgggcatccaggat- $3^{\prime}$ & \\
\hline \multirow[t]{2}{*}{ APOE } & Homo sapiens & $\mathrm{F}$ & $5^{\prime}$-ttcetggcaggatgccaggc $-3^{\prime}$ & NM_000041 \\
\hline & & $\mathrm{R}$ & $5^{\prime}$-ggtcagttgttcctccagttc- $3^{\prime}$ & \\
\hline \multirow[t]{2}{*}{ RAGE } & Homo sapiens & $\mathrm{F}$ & $5^{\prime}$-gagtccgtgtctaccagattcc- $3^{\prime}$ & NM_001136 \\
\hline & & $\mathrm{R}$ & $5^{\prime}$-atccaagtgccagctaagagtc- $3^{\prime}$ & \\
\hline \multirow[t]{2}{*}{ SCARB1 } & Homo sapiens & $\mathrm{F}$ & $5^{\prime}$-atcccettctatctctccgtct- $3^{\prime}$ & NM_005505 \\
\hline & & $\mathrm{R}$ & $5^{\prime}$-gtcgttgttgttgaaggtgatg- $3^{\prime}$ & \\
\hline \multirow[t]{2}{*}{ ACTB } & Homo sapiens & $\mathrm{F}$ & $5^{\prime}$-ggagcacagagcctcgcctt- $3^{\prime}$ & NM_173979 \\
\hline & & $\mathrm{R}$ & $5^{\prime}$-acatgccggagccgttgtcg- $3^{\prime}$ & \\
\hline \multirow[t]{2}{*}{ RPLP0 } & Homo sapiens & $\mathrm{F}$ & $5^{\prime}$-cagctgatcaagactggagaca- $3^{\prime}$ & NM_001002 \\
\hline & & $\mathrm{R}$ & $5^{\prime}$-cacttcagggttgtagatgctg- $3^{\prime}$ & \\
\hline
\end{tabular}

From left to right: the cDNA targeted for amplification, species, sequences (F, Forward; R, Reverse primer) and accession numbers of cDNA from the NCBI database.

cells were rinsed twice with warm ECM/0.05\% HSA, and cellular cholesterol efflux was assessed for $7 \mathrm{~h}$ in the presence or absence of $20 \mu \mathrm{g} / \mathrm{mL}$ cholesterol acceptors (ApoA-I, ApoE2, ApoE4) or $50 \mu \mathrm{g} / \mathrm{mL}$ HDL. At the end of this step, the medium was collected and centrifuged ( $4 \mathrm{~min}, 4000 \mathrm{rpm}, 4^{\circ} \mathrm{C}$ ). BLECs were washed four times with cold PBS and lysed with a PBS/1\% Triton X-100 buffer. Radioactivity in the supernatants and lysates was measured in a liquid scintillation counter (Tri-Carb 2100TR). The following equations were used to calculate percentage efflux from the disintegrations per minute (DPM) [29, 42]:

(1) percentage apical efflux $=\left(\mathrm{DPM}_{\text {apical }}\right) \times 100 /$ $\left(\mathrm{DPM}_{\text {apical }}+\mathrm{DPM}_{\text {basolateral }}+\mathrm{DPM}_{\text {celllysate }}\right)$

(2) percentage basolateral efflux $=\left(\mathrm{DPM}_{\text {basolateral }}\right) \times$ $100 /\left(\mathrm{DPM}_{\text {apical }}+\mathrm{DPM}_{\text {basolateral }}+\mathrm{DPM}_{\text {celllysate }}\right)$

Each assay was performed using three filters, and each experiment was run at least three times.

\section{Apical-to-basolateral transport of $A \beta$ peptides}

After a 24-h treatment with either DMSO (the control condition) or $100 \mathrm{nM}$ bexarotene, $\mathrm{A} \beta$ peptide influx (apical-to-basolateral transport) was measured, as previously described [29, 34]. For apical-to-basolateral studies, inserts with BLECs were transferred into 12-well plates containing $1.5 \mathrm{~mL}$ RH/0.5\% HSA in each well. Next, $0.5 \mathrm{~mL}$ RH/0.5\% $\mathrm{HSA} /$ sucrose with $10 \mathrm{nM}$ of either $\left[{ }^{3} \mathrm{H}\right]$-inulin or Cy5$\mathrm{A} \beta$ peptide were placed on the filters. For inhibition studies, the apical compartment was supplemented with $500 \mathrm{nM}$ elacridar. During the 30-min transport assay, cells were incubated at $37^{\circ} \mathrm{C}$ with very slight agitation. The BBB's permeability and non-receptormediated transport were respectively evaluated by measuring $\left[{ }^{14} \mathrm{C}\right]$ sucrose permeability (see below) and $\left[{ }^{3} \mathrm{H}\right]$-inulin transport using a liquid scintillation counter (TriCarb 2100TR, PerkinElmer). Radioactivity was measured in DPM. Fluorescence at appropriate wavelengths was measured using a spectrophotometer Synergy H1.

To assess possible adsorption to plastics and nonspecific binding to BLECs, the mass balance (\%) was calculated as the amount of compound recovered from both compartments at the end of the experiment divided by the total amount added to the donor compartment at time zero. The mass balance value should be between $90 \%$ and $110 \%$ since there is neither degradation nor aggregation of the molecules.

\section{Statistical analysis}

All statistical analyses were performed with Prism 6.0 software (GraphPad Software Inc., San Diego, CA, USA), using a one-way analysis of variance (ANOVA) and then appropriate post hoc tests. Data are reported as the mean \pm SD or (where specified) the mean \pm SEM. ${ }^{*} p<0.05 ;{ }^{* *} p<0.01 ;{ }^{* * *} p<0.001$.

\section{RESULTS}

Effect of bexarotene on the permeability of $B B B$

At concentrations of 25 to $100 \mathrm{nM}$, bexarotene did not modify the monolayer's permeability $(\mathrm{Pe})$ to the 
A

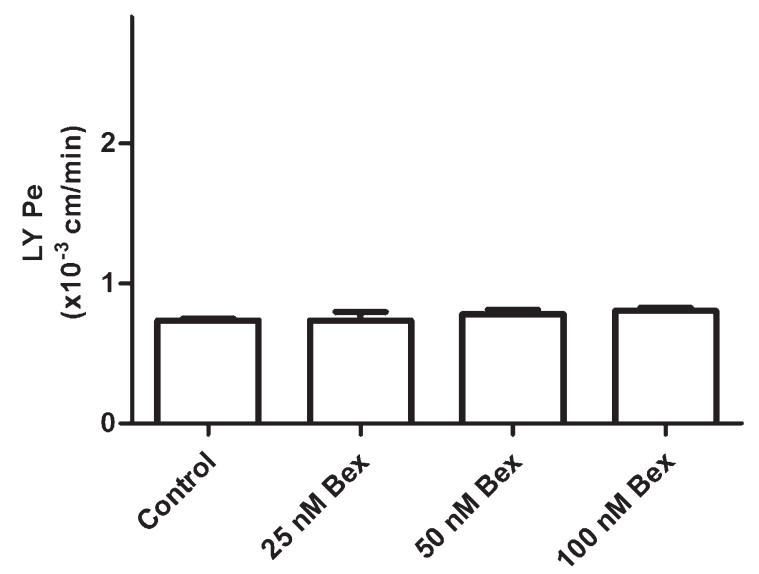

B

DMSO alone
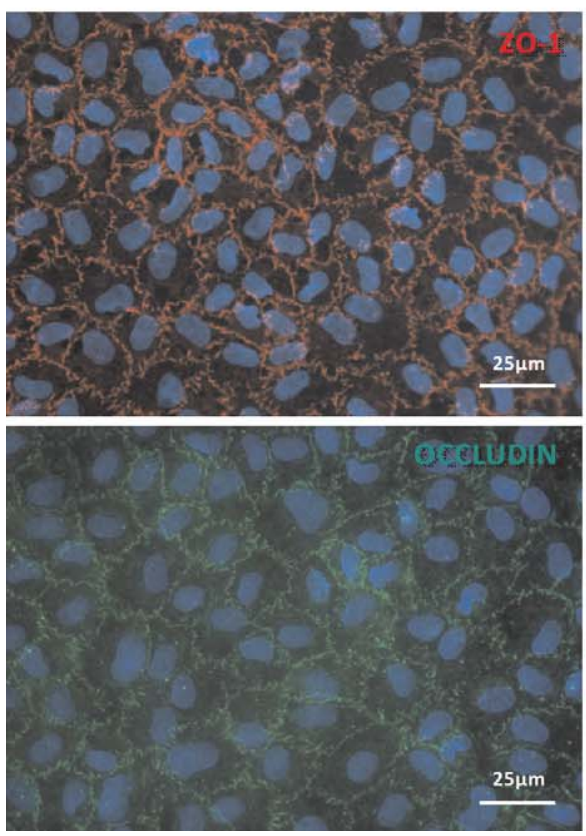

+100nM Bexarotene
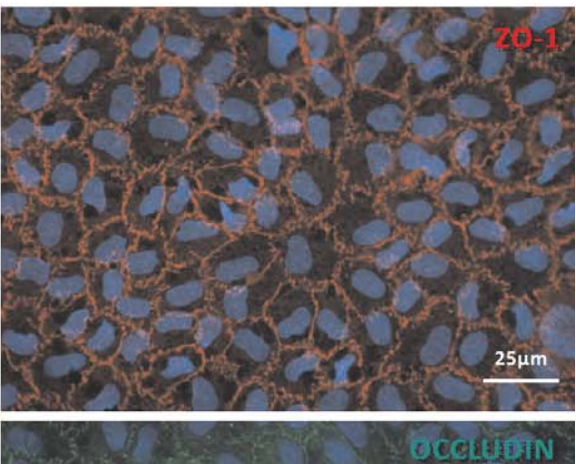

Fig. 1. Effect of bexarotene on BBB permeability (A) and tight junctions (B). In (A), different concentrations of bexarotene were incubated on the apical (blood) side of our human in vitro BBB model for $24 \mathrm{~h}$. Permeability (Pe) of a fluorescent paracellular marker (LY) was assessed as described in the Material and Methods and in previous studies [28, 39, 73]. Data are expressed as the mean \pm SEM. Statistical analysis: a one-way ANOVA followed by Dunnett's multiple comparison test, in which each condition is compared with the DMSO-treated control. In (B), the immunofluorescence localization of ZO1 (red) and occludin (green) was assessed after $24 \mathrm{~h}$ of treatment with DMSO or $100 \mathrm{nM}$ bexarotene. Nuclei were stained with Hoechst dye (blue). Scale bars correspond to $25 \mu \mathrm{m}$.

paracellular marker LY (Fig. 1A). The Pe values were correlated with immunohistochemical labeling of the tight junction protein ZO-1 and occludin (Fig. 1B).
Intact, strong staining of the junctions (with no gaps at cell borders) were observed in untreated and treated BLECs. 
Cholesterol efflux from BLECs

We and others have previously reported that cholesterol exchange between the brain and the blood is mediated by several proteins expressed by the ECs composing the BBB $[29,30,43,44]$. In the absence of treatment, BLECs loaded with radioactive cholesterol were able to efflux a small proportion $(0.86 \%$ in an HSA-only control condition) to the basolateral medium (the brain side, Fig. 2A). As we have previously observed in other brain vascular cell types [29, 42], the addition of lipid-free ApoA-I particles did not significantly increase the extent of release $(0.72 \%)$, whereas HDL, ApoE2, and ApoE4 increased release by up to 3-fold, compared with the HSA condition (2.71\%, $2.25 \%$, and $2.52 \%$, respectively). In the apical (bloodside) medium, the proportions of cholesterol efflux in the HSA- and in the ApoA-I particle-conditions were $2.17 \%$ and $2.01 \%$, respectively (Fig. 2B). Addition of HDL, ApoE2, and ApoE4 increased the proportion of cholesterol release to $6.33 \%, 5.74 \%$, and $5.37 \%$, respectively.

\section{Bexarotene induces ABCAl expression in BLECs}

Given that (1) bexarotene crosses the BBB and (2) BLECs express nuclear $R X R$, we next assessed the drug's influence on cholesterol exchange in the apical and basolateral compartments. Expression of ABCA1, SCARB1, and ApoE were investigated first with RT-qPCR assays and then in immunoblot experiments. Bexarotene upregulated transcription of $A B C A I$ (Fig. 3A) but not SCARBI or ApoE (Fig. 3B and C, respectively). These results were correlated with levels of protein expression (Fig. 3D).

\section{Bexarotene's upregulation of ABCA1 modulates cholesterol efflux}

Next, cholesterol efflux into the basolateral and apical compartments were assessed after $24 \mathrm{~h}$ of bexarotene treatment (100 nM). As shown in Fig. 4A, cholesterol release to acceptors in the basolateral compartment was significantly greater in the presence of bexarotene (with respective increases of $58.8 \%$, $30.5 \%, 41.1 \%$, and $19.8 \%$ in the presence of ApoA-I, HDL, ApoE2, and ApoE4, relative to the control conditions in the absence of bexarotene). Figure 4B shows the same trend in the apical compartment (with respective increases of $30.0 \%, 19.6 \%, 33.2 \%$, and $19.7 \%$ in the presence of ApoA-I, HDL, ApoE2, and ApoE4, relative to the control conditions).

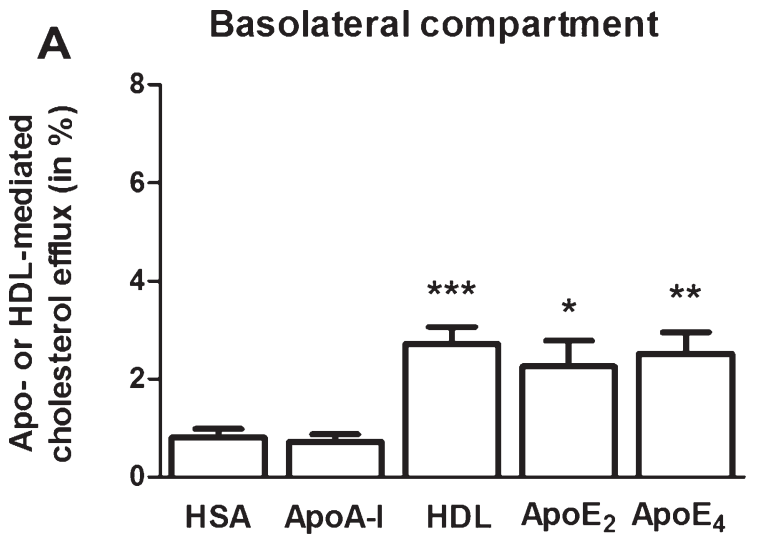

B

Apical compartment

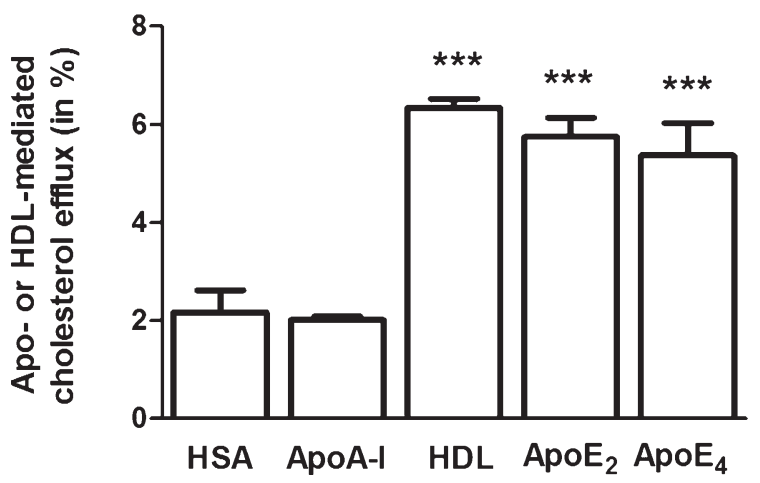

Fig. 2. Basal cholesterol efflux from BLECs. The BLECs were first labeled with $\left[{ }^{3} \mathrm{H}\right]$-cholesterol $(0.5 \mu \mathrm{Ci} / \mathrm{mL})$ for $36 \mathrm{~h}$ at $37^{\circ} \mathrm{C}$ and then equilibrated for $24 \mathrm{~h}$ in ECM/ $0.05 \% \mathrm{HSA}$ at $37^{\circ} \mathrm{C}$. Cholesterol release in the basolateral (A) and apical (B) compartments was measured after $7 \mathrm{~h}$ at $37^{\circ} \mathrm{C}$ either in the absence of any acceptors (HSA only) or in the presence of either ApoA-I $(20 \mu \mathrm{g} / \mathrm{mL})$, HDL $(50 \mu \mathrm{g} / \mathrm{mL})$, ApoE2 $(20 \mu \mathrm{g} / \mathrm{mL})$, or ApoE4 $(20 \mu \mathrm{g} / \mathrm{mL})$ particles in both compartments. Data are expressed as the mean \pm SEM. Statistical analysis: one-way ANOVA followed by Dunnett's test for multiple comparisons, where ${ }^{*} p<0.05$; $^{* *} p<0.01$; ${ }^{* * *} p<0.001$ relative to a DMSO-treated control.

\section{Apical-to-basolateral $A \beta$ peptide transport across} the $B B B$

We and others have previously demonstrated that RAGE, ABCB1, and ABCC1 are involved in the apical-to-basolateral transport of $\mathrm{A} \beta$ peptides. Bexarotene did not significantly modify the transcriptional expression of RAGE and ABCCl (1.16- and 1.19 -fold versus the control condition, respectively). After bexarotene treatment, however, the expression of $A B C B 1$ was significantly upregulated by a factor of 2.45 versus the control condition (Fig. 5A). This observation was confirmed by immunoblotting, where 
A
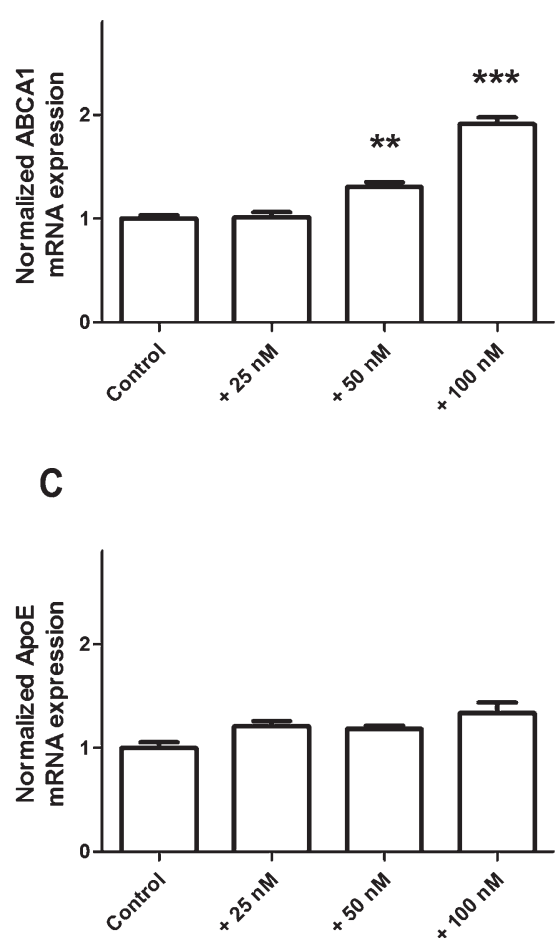

B

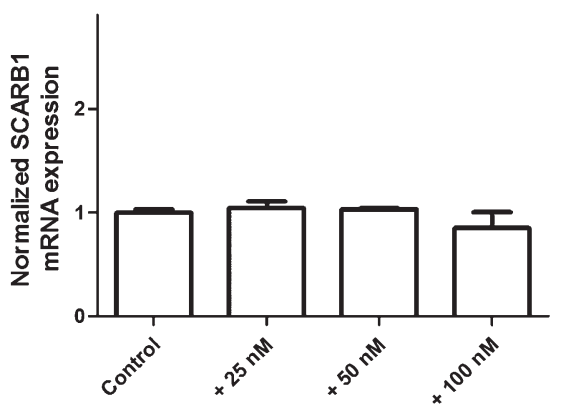

D

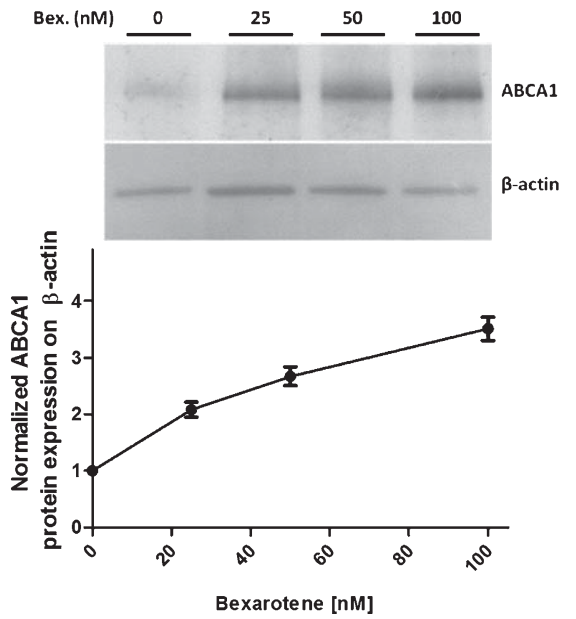

Fig. 3. Effect of bexarotene (100 nM) on expression of transporters involved in cholesterol release. Expression levels of $A B C A 1$ (A), SCARB1 (B), and $A p o E(\mathrm{C})$ were analyzed using RT-PCR assays and the primers listed in Table 1. Each bar represents the mRNA expression normalized against the housekeeping genes RPLP0 and ACTB and relative to the control condition. The results correspond to the mean \pm SEM of three experiments pooled from three filters. Statistical analysis: a one-way ANOVA followed by Dunnett's test for multiple comparisons, where ${ }^{*} p<0.05 ;{ }^{* *} p<0.01 ;{ }^{* * *} p<0.001$, relative to a DMSO-treated control. D) Normalized protein expression levels for ABCA1 were assessed by immunoblotting, as described in the Material and Methods section. $\beta$-actin was used as a loading control. The results correspond to the mean $\pm \mathrm{SD}$ of one experiment performed in triplicate and that was representative of two independent experiments.

expression of the $\mathrm{ABCB} 1$ protein was upregulated by 33\% (Fig. 5B).

\section{Upregulation of $A B C B 1$ decreases apical-to-basolateral $A \beta$ peptide transport}

In order to determine whether the upregulation of ABCB1 might affect apical-to-basolateral transport of $A \beta$ peptides, the transport experiments were performed using the potent $\mathrm{ABCB} 1$ inhibitor elacridar $[34,45]$. At a concentration of $500 \mathrm{nM}$, elacridar did not modify the monolayer's permeability to ${ }^{14}[\mathrm{C}]$ sucrose (data not shown). In our human BBB model, the apical-to-basolateral transport of the $A \beta$ peptides in the control condition was $1.28 \%$ (Fig. 6) after $30 \mathrm{~min}$. When BLECs were treated for $24 \mathrm{~h}$ with bexarotene, this transport decreased by about a quarter (to $0.96 \%$ ).
The transport was greater in the presence of elacridar than in the control condition (1.86\%). As in our previous studies of $A \beta$ peptide transport across the $\mathrm{BBB}$, inulin was included as a control because (1) its apparent molecular weight (almost $4.5 \mathrm{kDa}$ ) is very similar to those of the $A \beta$ peptides and (2) it lacks a specific receptor on the BLEC membrane [29, 34, 42, 46]. Neither bexarotene nor elacridar significantly affected the apical-to-basolateral transport of inulin (data not shown).

\section{DISCUSSION}

Dysregulation of brain cholesterol metabolism and $\mathrm{A} \beta$ peptide transport across the $\mathrm{BBB}$ are thought to have a key role in the development of AD [25, 47]. At present, one of the most interesting approaches for 


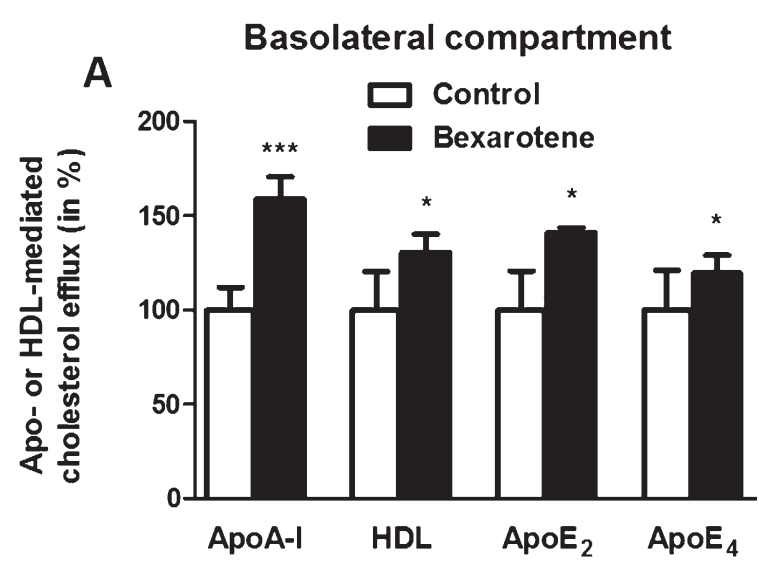

B

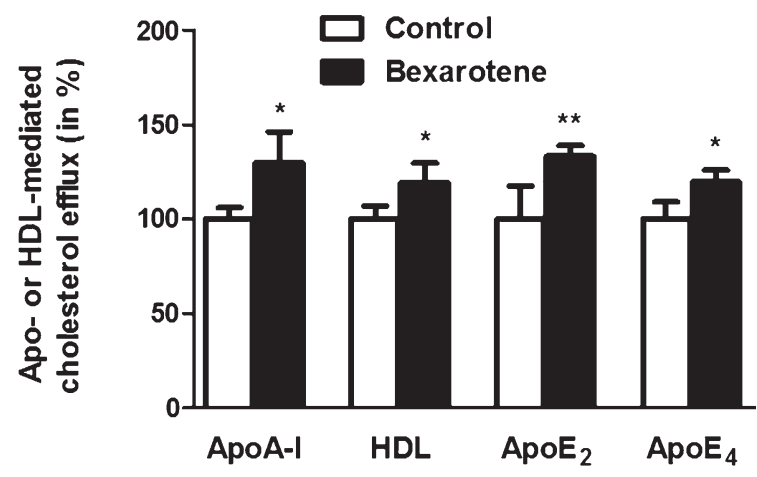

Fig. 4. The effect of bexarotene on cholesterol release. To determine the effect of bexarotene on cholesterol efflux into the basolateral (A) and apical (B) compartments, the equilibration step was performed in the presence of DMSO alone (control) or $100 \mathrm{nM}$ bexarotene. Acceptors were added in both compartments. Each bar represents the mean \pm SEM; $n=6-12 .{ }^{*} p<0.05 ;{ }^{* *} p<0.01 ;{ }^{* * *} p<0.001$, relative to a DMSO-treated control (in a one-way ANOVA, followed by Bonferroni's test for multiple comparisons).

treating $\mathrm{AD}$ is the administration of bexarotene [24, 48, 49], an RXR agonist that modulates the expression of ABCA1 and ApoE (both of which are major proteins regulating cholesterol homeostasis in the brain and periphery). ABCA1 is the major transporter in the lipidation of ApoE, whereas the latter is involved in $A \beta$ peptide metabolism and clearance. This clearance can be promoted by microglial phagocytosis or transport across the BBB. However, bexarotene's effect on $A \beta$ peptide clearance from the brain is still subject to debate. Whereas some studies report a decrease in soluble forms of brain $A \beta$ peptides [17, 18, 23], other studies failed to observe an effect [20, 21, 50, 51]. Behavioral studies of bexarotene-treated AD animals have either reported no improvement $[19,21,50,51]$

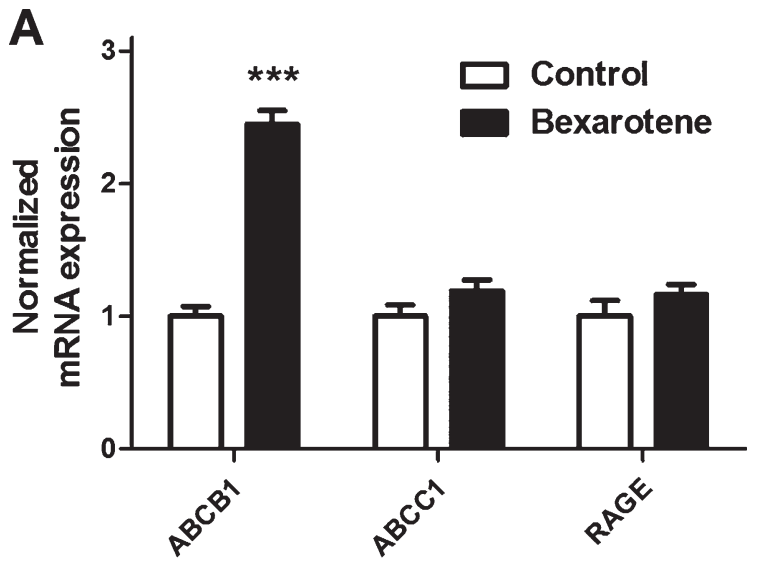

B

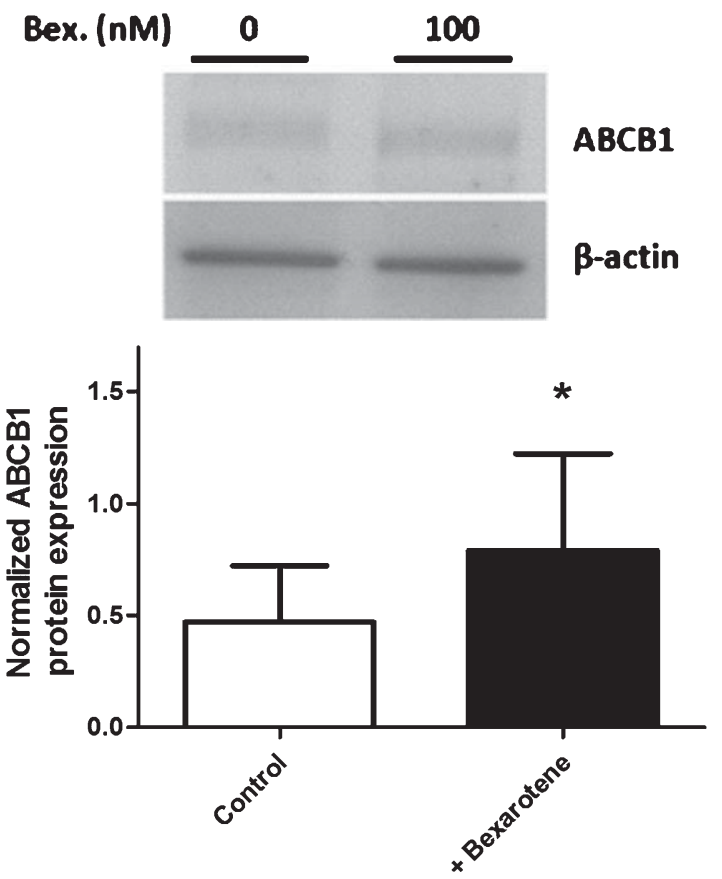

Fig. 5. The effect of bexarotene $(100 \mathrm{nM})$ on expression of transporters involved in $A \beta$ peptide influx across BLECs. In (A), cells were pretreated for $24 \mathrm{~h}$ with DMSO (control) or bexarotene (100 nM). $A B C B 1, R A G E$, and $A B C C 1$ were analyzed using RT-qPCR assays and the primers listed in Table 1. Each bar corresponds to the mean \pm SEM of mRNA expression, normalized against $R P L P O$ and $A C T B$. In (B), protein expression of ABCB1 was assessed by immunoblotting after BLECs had been treated for $24 \mathrm{~h}$ with either DMSO or bexarotene (100 nM). Each bar corresponds to the mean \pm SD. Statistical analysis: a one-way ANOVA, followed by Dunnett's test for multiple comparisons, where ${ }^{*} p<0.05 ;{ }^{* *} p<0.001$, relative to a DMSO-treated control. 


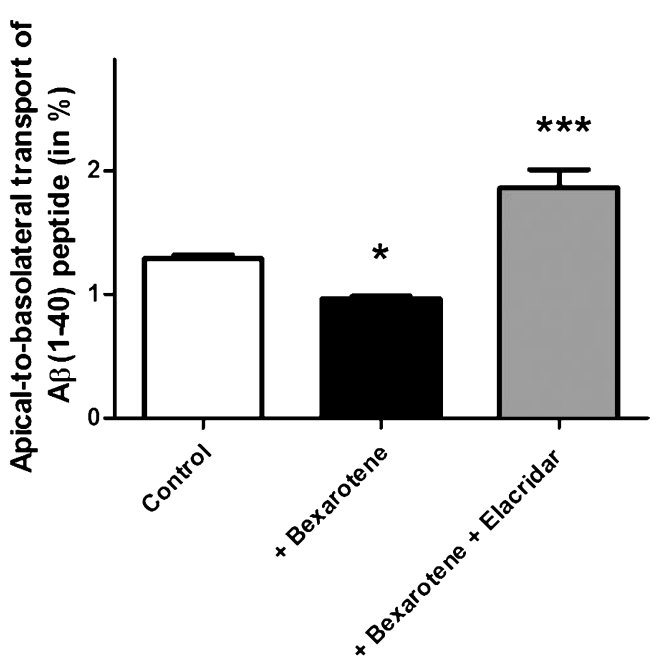

Fig. 6. Apical-to-basolateral transport of $A \beta$ peptides after treatment with $100 \mathrm{nM}$ bexarotene in the presence $(500 \mathrm{nM})$ or absence of the ABCB1 inhibitor elacridar [34]. Inulin is used as a non-specific vesicular transport marker (data not shown). Each bar corresponds to the mean $\pm \mathrm{SD} ; n=6 .{ }^{*} p<0.05 ;{ }^{* * *} p<0.001$ compared with the DMSO-treated control (in a one-way ANOVA, followed by Dunnett's test for multiple comparisons).

or some improvement $[17,18]$, relative to untreated animals. Although it has been suggested that these discrepancies are due to differences in the formulation of bexarotene use, another possible explanation relates to the use of aggressive transgenic mouse models of AD. Indeed, several studies have highlighted that genetic modifications altering the amyloid synthesis can alter the physiological properties of the BBB in these models-often before the onset of the disease itself. For example, the BBB's integrity $[52,53]$ and the brain's vascular volume and expression of receptors and transporters $[54,55]$ are rapidly altered in murine models of AD. Accordingly, we hypothesized that bexarotene acts at the BBB level to influence the amyloid burden and the brain's cholesterol metabolism. However, these effects cannot be observed in models in which the BBB's physiology and integrity are modified.

Hence, by using an in vitro model of the human BBB in which BLECs are cultured with brain pericytes [39], we sought to characterize bexarotene's effects on BBB permeability, cholesterol exchange, and $A \beta$ peptide re-entry into the CNS.

In vitro, we used the same bexarotene concentrations used in the literature. These were not toxic and did not modify the permeability of the BBB in our culture system. Thus, a bexarotene concentration of $100 \mathrm{nM}$ was used in all of our experiments.
Next, we investigated ABCA1 expression in our model. This transporter is of prime interest in $\mathrm{AD}$ because its impact on brain cholesterol metabolism modulates the brain's amyloid burden. Whereas overexpression of ABCA1 decreases the amyloid accumulation [14], knock-out of this gene provokes an accumulation of $\mathrm{A} \beta$ peptide in the CNS $[12,13,56]$. It has previously been reported that ABCA1 is expressed by brain microvessel ECs from animals [29, 30, 57]. Here, for the first time, we demonstrated that this transporter is also expressed by human BBB cells. Furthermore, our data showed that bexarotene-mediated upregulation of ABCA1 in BLECs is correlated with an increase in cholesterol efflux to ApoA-I, HDL, ApoE2, and ApoE4 particles. Because membrane cholesterol content influences also the ABCA1 activity [58], it is likely that bexarotene also modulates the ABCA1 activity. Interestingly, and as previously reported for brain pericytes [42], neurons [59], fibroblasts [60], and plexus choroid cells [61], there were no significant differences in efflux between the two isoforms of ApoE. The cholesterol efflux is preferentially directed to the apical compartment (the blood side) and probably helps regulating the cerebral pool of cholesterol. Taken as a whole, these data strongly reinforce the hypothesis whereby the human BBB is involved in cholesterol homeostasis in the brain and the periphery $[29,31,42,62]$. Thus, we hypothesized that if the physiology of the BBB is altered (as in several murine models of AD [19-21, 50]), bexarotene will have less effect on the brain's cholesterol metabolism.

Interestingly, we also observed that bexarotene did not modulate the expression of ApoE by BLECs. Bexarotene has been shown to induce the expression of ApoE in several CNS cell types and in brain extracts [17, 63, 64] but not in hippocampal neurons [48]. The levels of ApoE and HDL (or HDL-like particles) are important parameters for the cholesterol shuttle between neurons and astrocytes and for the BBBmediated clearance of $\mathrm{A} \beta$ peptides $[9,25,47]$.

For example, previous research has demonstrated that bexarotene can promote the brain-to-blood transport of $A \beta$ peptides in vitro and in vivo in the presence of ApoE [65]. This effect is probably mediated by an increase in the expression of receptors such as the lowdensity lipoprotein receptors (LRP1, LDLR, vLDLR, etc.) involved in $A \beta$ peptide clearance across the BBB. However, the above-cited study did not investigate the receptors' expression and functionality [65]. Given that we have previously characterized the role of RAGE and $\mathrm{ABCB} 1$ in the re-entry of $\mathrm{A} \beta$ peptides into the CNS $[29,34,42]$, we decided to investigate bexarotene's 
effects on the apical-to-basolateral transport of these peptides. Although the impact of circulating levels of $\mathrm{A} \beta$ peptides in $\mathrm{AD}$ is often neglected, several studies have now highlighted the need to consider this peripheral pool in the disease mechanism $[33,35,36]$. RAGE is exclusively expressed at the apical side of the brain ECs and mediates the entry of the $\mathrm{A} \beta$ peptide into the brain via a caveola-mediated process [32]. ABCB1 is expressed in a wide range of cells and tissues and was the first $\mathrm{ABC}$ transporter to be found in the $\mathrm{BBB}$ [66]. It was initially described as restricting the entry of xenobiotics into the CNS, but it is now clear that $A B C B 1$ is also involved in $\mathrm{A} \beta$ peptide transport across the $\mathrm{BBB}$. Whereas some studies have reported a role for ABCB1 in $A \beta$ peptide elimination from the brain $[37,67]$, others have demonstrated that this transporter restricts the re-entry of these peptides into the CNS [34, 45]. More recently, it has been suggested that $\mathrm{ABCC} 1$ (another efflux pump expressed by $B B B$ cells) mediates $A \beta$ peptide transport across the BBB [37]. As a consequence, the modulation of the expression and function of these $\mathrm{ABC}$ transporters appears to be an attractive approach to the development of $\mathrm{AD}$ treatments [37, 68].

Our results showed that treatment with bexarotene provoked upregulation of the ABCB1 transporter and thus a decrease in $A \beta$ peptide entry into the brain compartment. The expression of ABCC 1 and RAGE was not modified by the treatment. The results of our experiments with the specific ABCB1 inhibitor elacridar [34, 45] definitively confirmed that the process was $\mathrm{ABCB} 1-$ mediated, since the compound restored apical-to-basolateral $A \beta$ peptide transport across the BBB. To the best of our knowledge, the present study is the first to report the bexarotenemediated regulation of $\mathrm{ABCB} 1$ in the $\mathrm{BBB}$. It is now acknowledged that ABCB1's function and expression are closely linked to the lipid composition of cell membranes and the cellular cholesterol content [69, 70]. Previous studies have reported that the expression of this transporter is regulated by the liver $\mathrm{X}$ receptor (LXR) partner [47, 71]. Therefore, bexarotene might upregulate $\mathrm{ABCB} 1$ expression via the formation of RXR/LXR heterodimers; this would be a very attractive therapeutic approach for AD [72].

In summary, our present observations suggest that bexarotene can act on $\mathrm{AD}$ at several levels. Firstly, bexarotene modifies the brain's cholesterol metabolism via an ABCA1- and ApoE-dependent process. How this process affects the brain's functions and behavior requires further investigation, but it is likely that these modifications also impact $A \beta$ peptide synthesis and macrophage-mediated $A \beta$ clearance.
Secondly, bexarotene acts directly at the BBB by modulating the transport of $A \beta$ peptides. The brain efflux of $A \beta$ peptide across the $B B B$ is increased [65], and the influx of soluble forms of $A \beta$ peptide across BLECs (in the apical-to-basolateral direction) is decreased; this could reduce $A \beta$ re-entry into the brain and thus limit further accumulation within this compartment.

In conclusion, our present results add to the growing body of evidence to show that bexarotene can act at the BBB to decrease the amyloid burden in AD patients and animal models. As found in previous studies [29, 43, 68], our present results suggest that nuclear receptors (RXRs, LXRs, and others) are promising drug targets for modulating the BBB's physiology and treating CNS pathologies.

\section{ACKNOWLEDGMENTS}

Julien Saint-Pol and Yordenca Lamartinière received doctoral fellowships from the French Ministry of Higher Education and Research (Ministère de l'Enseignement Supérieur et de la Recherche). We thank Anne-Marie Lenfant for excellent technical assistance.

Authors' disclosures available online (http://j-alz. com/manuscript-disclosures/15-0469r1).

\section{REFERENCES}

[1] Hardy JA, Higgins GA (1992) Alzheimer's disease: The amyloid cascade hypothesis. Science 256, 184-185.

[2] Selkoe DJ (2001) Alzheimer's disease: Genes, proteins, and therapy. Physiol Rev 81, 741-766.

[3] Kivipelto M, Helkala EL, Laakso MP, Hanninen T, Hallikainen M, Alhainen K, Soininen H, Tuomilehto J, Nissinen A (2001) Midlife vascular risk factors and Alzheimer's disease in later life: Longitudinal, population based study. BMJ 322, 1447-1451.

[4] Solomon A, Kivipelto M, Wolozin B, Zhou J, Whitmer RA (2009) Midlife serum cholesterol and increased risk of Alzheimer's and vascular dementia three decades later. Dement Geriatr Cogn Disord 28, 75-80.

[5] Hooijmans CR, Van der Zee CE, Dederen PJ, Brouwer KM, Reijmer YD, van Groen T, Broersen LM, Lutjohann D, Heerschap A, Kiliaan AJ (2009) DHA and cholesterol containing diets influence Alzheimer-like pathology, cognition and cerebral vasculature in APPswe/PS1dE9 mice. Neurobiol Dis 33, 482-498.

[6] Refolo LM, Malester B, LaFrancois J, Bryant-Thomas T, Wang R, Tint GS, Sambamurti K, Duff K, Pappolla MA (2000) Hypercholesterolemia accelerates the Alzheimer's amyloid pathology in a transgenic mouse model. Neurobiol Dis 7, 321-331.

[7] Sparks DL, Scheff SW, Hunsaker JC, 3rd, Liu H, Landers T, Gross DR (1994) Induction of Alzheimer-like beta-amyloid 
immunoreactivity in the brains of rabbits with dietary cholesterol. Exp Neurol 126, 88-94.

[8] Strittmatter WJ, Saunders AM, Schmechel D, Pericak-Vance M, Enghild J, Salvesen GS, Roses AD (1993) Apolipoprotein E: High-avidity binding to beta-amyloid and increased frequency of type 4 allele in late-onset familial Alzheimer disease. Proc Natl Acad Sci U S A 90, 1977-1981.

[9] Hirsch-Reinshagen V, Wellington CL (2007) Cholesterol metabolism, apolipoprotein E, adenosine triphosphatebinding cassette transporters, and Alzheimer's disease. Curr Opin Lipidol 18, 325-332.

[10] Koldamova R, Fitz NF, Lefterov I (2010) The role of ATPbinding cassette transporter A1 in Alzheimer's disease and neurodegeneration. Biochim Biophys Acta 1801, 824-830.

[11] Koldamova R, Staufenbiel M, Lefterov I (2005) Lack of ABCA1 considerably decreases brain ApoE level and increases amyloid deposition in APP23 mice. J Biol Chem 280, 43224-43235.

[12] Hirsch-Reinshagen V, Maia LF, Burgess BL, Blain JF, Naus KE, McIsaac SA, Parkinson PF, Chan JY, Tansley GH, Hayden MR, Poirier J, Van Nostrand W, Wellington CL (2005) The absence of ABCA1 decreases soluble ApoE levels but does not diminish amyloid deposition in two murine models of Alzheimer disease. J Biol Chem 280, 43243-43256.

[13] Wahrle SE, Jiang H, Parsadanian M, Hartman RE, Bales KR, Paul SM, Holtzman DM (2005) Deletion of Abcal increases Abeta deposition in the PDAPP transgenic mouse model of Alzheimer disease. J Biol Chem 280, 43236-43242.

[14] Wahrle SE, Jiang H, Parsadanian M, Kim J, Li A, Knoten A, Jain S, Hirsch-Reinshagen V, Wellington CL, Bales KR, Paul SM, Holtzman DM (2008) Overexpression of ABCA1 reduces amyloid deposition in the PDAPP mouse model of Alzheimer disease. J Clin Invest 118, 671-682.

[15] Koldamova RP, Lefterov IM, Staufenbiel M, Wolfe D, Huang S, Glorioso JC, Walter M, Roth MG, Lazo JS (2005) The liver $\mathrm{X}$ receptor ligand T0901317 decreases amyloid beta production in vitro and in a mouse model of Alzheimer's disease. J Biol Chem 280, 4079-4088.

[16] Donkin JJ, Stukas S, Hirsch-Reinshagen V, Namjoshi D, Wilkinson A, May S, Chan J, Fan J, Collins J, Wellington CL (2010) ATP-binding cassette transporter A1 mediates the beneficial effects of the liver X receptor agonist GW3965 on object recognition memory and amyloid burden in amyloid precursor protein/presenilin 1 mice. J Biol Chem 285, 34144-34154.

[17] Cramer PE, Cirrito JR, Wesson DW, Lee CY, Karlo JC, Zinn AE, Casali BT, Restivo JL, Goebel WD, James MJ, Brunden KR, Wilson DA, Landreth GE (2012) ApoE-directed therapeutics rapidly clear beta-amyloid and reverse deficits in $\mathrm{AD}$ mouse models. Science 335, 1503-1506.

[18] Fitz NF, Cronican AA, Lefterov I, Koldamova R (2013) Comment on "ApoE-directed therapeutics rapidly clear betaamyloid and reverse deficits in AD mouse models". Science 340, 924-c.

[19] LaClair KD, Manaye KF, Lee DL, Allard JS, Savonenko AV, Troncoso JC, Wong PC (2013) Treatment with bexarotene, a compound that increases apolipoprotein-E, provides no cognitive benefit in mutant APP/PS1 mice. Mol Neurodegener 8,18 .

[20] Price AR, Xu G, Siemienski ZB, Smithson LA, Borchelt DR, Golde TE, Felsenstein KM (2013) Comment on "ApoEdirected therapeutics rapidly clear beta-amyloid and reverse deficits in AD mouse models". Science 340, 924-d.

[21] Tesseur I, Lo AC, Roberfroid A, Dietvorst S, Van Broeck B, Borgers M, Gijsen H, Moechars D, Mercken M, Kemp
J, D’Hooge R, De Strooper B (2013) Comment on “ApoEdirected therapeutics rapidly clear beta-amyloid and reverse deficits in AD mouse models". Science 340, 924-e.

[22] Ulrich JD, Burchett JM, Restivo JL, Schuler DR, Verghese PB, Mahan TE, Landreth GE, Castellano JM, Jiang H, Cirrito JR, Holtzman DM (2013) In vivo measurement of apolipoprotein $\mathrm{E}$ from the brain interstitial fluid using microdialysis. $\mathrm{Mol}$ Neurodegener $\mathbf{8}, 13$.

[23] Veeraraghavalu K, Zhang C, Miller S, Hefendehl JK, Rajapaksha TW, Ulrich J, Jucker M, Holtzman DM, Tanzi RE, Vassar R, Sisodia SS (2013) Comment on "ApoE-directed therapeutics rapidly clear beta-amyloid and reverse deficits in AD mouse models". Science 340, 924-f.

[24] Tousi B (2015) The emerging role of bexarotene in the treatment of Alzheimer's disease: Current evidence. $\mathrm{Neu}$ ropsychiatr Dis Treat 11, 311-315.

[25] Gosselet F, Saint-Pol J, Candela P, Fenart L (2013) Amyloidbeta peptides, Alzheimer's disease and the blood-brain barrier. Curr Alzheimer Res 10, 1015-1033.

[26] Zlokovic BV (2005) Neurovascular mechanisms of Alzheimer's neurodegeneration. Trends Neurosci 28, 202208.

[27] Zlokovic BV (2008) The blood-brain barrier in health and chronic neurodegenerative disorders. Neuron 57, 178-201.

[28] Cecchelli R, Berezowski V, Lundquist S, Culot M, Renftel M, Dehouck MP, Fenart L (2007) Modelling of the blood-brain barrier in drug discovery and development. Nat Rev Drug Discov 6, 650-661.

[29] Saint-Pol J, Candela P, Boucau MC, Fenart L, Gosselet F (2013) Oxysterols decrease apical-to-basolateral transport of $\mathrm{A} \beta$ peptides via an $\mathrm{ABCB} 1$-mediated process in an in vitro blood-brain barrier model constituted of bovine brain capillary endothelial cells. Brain Res 1517, 1-15.

[30] Panzenboeck U, Balazs Z, Sovic A, Hrzenjak A, Levak-Frank S, Wintersperger A, Malle E, Sattler W (2002) ABCA1 and scavenger receptor class B, type I, are modulators of reverse sterol transport at an in vitro blood-brain barrier constituted of porcine brain capillary endothelial cells. J Biol Chem 277, 42781-42789.

[31] Do TM, Ouellet M, Calon F, Chimini G, Chacun H, Farinotti R, Bourasset F (2011) Direct evidence of abca1-mediated efflux of cholesterol at the mouse blood-brain barrier. $\mathrm{Mol}$ Cell Biochem 357, 397-404.

[32] Deane R, Du Yan S, Submamaryan RK, LaRue B, Jovanovic S, Hogg E, Welch D, Manness L, Lin C, Yu J, Zhu H, Ghiso J, Frangione B, Stern A, Schmidt AM, Armstrong DL, Arnold B, Liliensiek B, Nawroth P, Hofman F, Kindy M, Stern D, Zlokovic B (2003) RAGE mediates amyloid-beta peptide transport across the blood-brain barrier and accumulation in brain. Nat Med 9, 907-913.

[33] Deane R, Singh I, Sagare AP, Bell RD, Ross NT, LaRue B, Love R, Perry S, Paquette N, Deane RJ, Thiyagarajan M, Zarcone T, Fritz G, Friedman AE, Miller BL, Zlokovic BV (2012) A multimodal RAGE-specific inhibitor reduces amyloid beta-mediated brain disorder in a mouse model of Alzheimer disease. J Clin Invest 122, 1377-1392.

[34] Candela P, Gosselet F, Saint-Pol J, Sevin E, Boucau MC, Boulanger E, Cecchelli R, Fenart L (2010) Apicalto-basolateral transport of amyloid-beta peptides through blood-brain barrier cells is mediated by the receptor for advanced glycation end-products and is restricted by $\mathrm{P}_{-}$ glycoprotein. J Alzheimers Dis 22, 849-859.

[35] Eisele YS, Obermuller U, Heilbronner G, Baumann F, Kaeser SA, Wolburg H, Walker LC, Staufenbiel M, Heikenwalder 
M, Jucker M (2010) Peripherally applied Abeta-containing inoculates induce cerebral beta-amyloidosis. Science 330, 980-982.

[36] Sutcliffe JG, Hedlund PB, Thomas EA, Bloom FE, Hilbush BS (2011) Peripheral reduction of beta-amyloid is sufficient to reduce brain beta-amyloid: Implications for Alzheimer's disease. J Neurosci Res 89, 808-814.

[37] Krohn M, Lange C, Hofrichter J, Scheffler K, Stenzel J, Steffen J, Schumacher T, Bruning T, Plath AS, Alfen F, Schmidt A, Winter F, Rateitschak K, Wree A, Gsponer J, Walker LC, Pahnke J (2011) Cerebral amyloid-beta proteostasis is regulated by the membrane transport protein $\mathrm{ABCC} 1$ in mice. J Clin Invest 121, 3924-3931.

[38] Krohn M, Bracke A, Avchalumov Y, Schumacher T, Hofrichter J, Paarmann K, Frohlich C, Lange C, Bruning T, von Bohlen Und Halbach O, Pahnke J (2015) Accumulation of murine amyloid-beta mimics early Alzheimer's disease. Brain 138(Pt 8), 2370-2382.

[39] Cecchelli R, Aday S, Sevin E, Almeida C, Culot M, Dehouck L, Coisne C, Engelhardt B, Dehouck MP, Ferreira L (2014) A stable and reproducible human blood-brain barrier model derived from hematopoietic stem cells. PLoS One 9, e99733.

[40] Pedroso DC, Tellechea A, Moura L, Fidalgo-Carvalho I, Duarte J, Carvalho E, Ferreira L (2011) Improved survival, vascular differentiation and wound healing potential of stem cells co-cultured with endothelial cells. PLoS One 6, e16114.

[41] Vandenhaute E, Dehouck L, Boucau MC, Sevin E, Uzbekov R, Tardivel M, Gosselet F, Fenart L, Cecchelli R, Dehouck MP (2011) Modelling the neurovascular unit and the blood-brain barrier with the unique function of pericytes. Curr Neurovasc Res 8, 258-269.

[42] Saint-Pol J, Vandenhaute E, Boucau MC, Candela P, Dehouck L, Cecchelli R, Dehouck MP, Fenart L, Gosselet F (2012) Brain pericytes ABCA1 expression mediates cholesterol efflux but not cellular amyloid-beta peptide accumulation. J Alzheimers Dis 30, 489-503.

[43] Panzenboeck U, Kratzer I, Sovic A, Wintersperger A, Bernhart E, Hammer A, Malle E, Sattler W (2006) Regulatory effects of synthetic liver $\mathrm{X}$ receptor- and peroxisomeproliferator activated receptor agonists on sterol transport pathways in polarized cerebrovascular endothelial cells. Int J Biochem Cell Biol 38, 1314-1329.

[44] Gosselet F, Candela P, Sevin E, Berezowski V, Cecchelli R, Fenart L (2009) Transcriptional profiles of receptors and transporters involved in brain cholesterol homeostasis at the blood-brain barrier: Use of an in vitro model. Brain Res 1249 , 34-42.

[45] Tai LM, Loughlin AJ, Male DK, Romero IA (2009) P-glycoprotein and breast cancer resistance protein restrict apical-to-basolateral permeability of human brain endothelium to amyloid-beta. J Cereb Blood Flow Metab 29, 1079-1083.

[46] Brillault J, Berezowski V, Cecchelli R, Dehouck MP (2002) Intercommunications between brain capillary endothelial cells and glial cells increase the transcellular permeability of the blood-brain barrier during ischaemia. J Neurochem $\mathbf{8 3}$, 807-817.

[47] Gosselet F, Saint-Pol J, Fenart L (2014) Effects of oxysterols on the blood-brain barrier: Implications for Alzheimer's disease. Biochem Biophys Res Commun 446, 687-691.

[48] Boehm-Cagan A, Michaelson DM (2014) Reversal of apoE4driven brain pathology and behavioral deficits by bexarotene. J Neurosci 34, 7293-7301.

[49] Lalloyer F, Fievet C, Lestavel S, Torpier G, van der Veen J, Touche V, Bultel S, Yous S, Kuipers F, Paumelle R, Fruchart
JC, Staels B, Tailleux A (2006) The RXR agonist bexarotene improves cholesterol homeostasis and inhibits atherosclerosis progression in a mouse model of mixed dyslipidemia. Arterioscler Thromb Vasc Biol 26, 2731-2737.

[50] Balducci C, Paladini A, Micotti E, Tolomeo D, La Vitola P, Grigoli E, Richardson JC, Forloni G (2015) The continuing failure of bexarotene in Alzheimer's disease mice. J Alzheimers Dis 46, 471-482.

[51] O'Hare E, Jeggo R, Kim EM, Barbour B, Walczak JS, Palmer P, Lyons T, Page D, Hanna D, Meara JR, Spanswick D, Guo JP, McGeer EG, McGeer PL, Hobson P (2015) Lack of support for bexarotene as a treatment for Alzheimer's disease. Neuropharmacology, in press.

[52] Ujiie M, Dickstein DL, Carlow DA, Jefferies WA (2003) Blood-brain barrier permeability precedes senile plaque formation in an Alzheimer disease model. Microcirculation 10, 463-470.

[53] Paul J, Strickland S, Melchor JP (2007) Fibrin deposition accelerates neurovascular damage and neuroinflammation in mouse models of Alzheimer's disease. J Exp Med 204, 19992008.

[54] Do TM, Alata W, Dodacki A, Traversy MT, Chacun H, Pradier L, Scherrmann JM, Farinotti R, Calon F, Bourasset F (2014) Altered cerebral vascular volumes and solute transport at the blood-brain barriers of two transgenic mouse models of Alzheimer's disease. Neuropharmacology 81, 311-317.

[55] Bourasset F, Ouellet M, Tremblay C, Julien C, Do TM, Oddo S, LaFerla F, Calon F (2009) Reduction of the cerebrovascular volume in a transgenic mouse model of Alzheimer's disease. Neuropharmacology 56, 808-813.

[56] Fitz NF, Cronican AA, Saleem M, Fauq AH, Chapman R, Lefterov I, Koldamova R (2012) Abca1 deficiency affects Alzheimer's disease-like phenotype in human ApoE4 but not in ApoE3-targeted replacement mice. J Neurosci 32, 1312513136.

[57] Akanuma S, Hori S, Ohtsuki S, Fujiyoshi M, Terasaki T (2008) Expression of nuclear receptor mRNA and liver $\mathrm{X}$ receptor-mediated regulation of $\mathrm{ABC}$ transporter $\mathrm{A} 1$ at rat blood-brain barrier. Neurochem Int 52, 669-674.

[58] Takahashi K, Kimura Y, Kioka N, Matsuo M, Ueda K (2006) Purification and ATPase activity of human ABCA1. J Biol Chem 281, 10760-10768.

[59] Kim WS, Rahmanto AS, Kamili A, Rye KA, Guillemin GJ, Gelissen IC, Jessup W, Hill AF, Garner B (2007) Role of ABCG1 and ABCA1 in regulation of neuronal cholesterol efflux to apolipoprotein E discs and suppression of amyloidbeta peptide generation. J Biol Chem 282, 2851-2861.

[60] Krimbou L, Denis M, Haidar B, Carrier M, Marcil M, Genest J Jr (2004) Molecular interactions between apoE and ABCA1: Impact on apoE lipidation. J Lipid Res 45, 839-848.

[61] Fujiyoshi M, Ohtsuki S, Hori S, Tachikawa M, Terasaki T (2007) 24S-hydroxycholesterol induces cholesterol release from choroid plexus epithelial cells in an apical- and apoE isoform-dependent manner concomitantly with the induction of ABCA1 and ABCG1 expression. J Neurochem 100, 968-978.

[62] Karasinska JM, Rinninger F, Lutjohann D, Ruddle P, Franciosi S, Kruit JK, Singaraja RR, Hirsch-Reinshagen V, Fan J, Brunham LR, Bissada N, Ramakrishnan R, Wellington CL, Parks JS, Hayden MR (2009) Specific loss of brain ABCA1 increases brain cholesterol uptake and influences neuronal structure and function. J Neurosci 29 , 3579-3589. 
[63] Xu L, Cao F, Xu F, He B, Dong Z (2015) Bexarotene reduces blood-brain barrier permeability in cerebral ischemiareperfusion injured rats. PLoS One 10, e0122744.

[64] Zhao J, Fu Y, Liu CC, Shinohara M, Nielsen HM, Dong Q, Kanekiyo T, Bu G (2014) Retinoic acid isomers facilitate apolipoprotein $\mathrm{E}$ production and lipidation in astrocytes through the retinoid $\mathrm{X}$ receptor/retinoic acid receptor pathway. J Biol Chem 289, 11282-11292.

[65] Bachmeier C, Beaulieu-Abdelahad D, Crawford F, Mullan M, Paris D (2013) Stimulation of the retinoid X receptor facilitates beta-amyloid clearance across the blood-brain barrier. J Mol Neurosci 49, 270-276.

[66] Cordon-Cardo C, O'Brien JP, Casals D, RittmanGrauer L, Biedler JL, Melamed MR, Bertino JR (1989) Multidrug-resistance gene (P-glycoprotein) is expressed by endothelial cells at blood-brain barrier sites. Proc Natl Acad Sci U S A 86, 695-698.

[67] Cirrito JR, Deane R, Fagan AM, Spinner ML, Parsadanian M, Finn MB, Jiang H, Prior JL, Sagare A, Bales KR, Paul SM, Zlokovic BV, Piwnica-Worms D, Holtzman DM (2005) P-glycoprotein deficiency at the blood-brain barrier increases amyloid-beta deposition in an Alzheimer disease mouse model. J Clin Invest 115, 3285-3290.

[68] Hartz AM, Miller DS, Bauer B (2010) Restoring blood-brain barrier P-glycoprotein reduces brain amyloid-beta in a mouse model of Alzheimer's disease. Mol Pharmacol 77, 715-723.
[69] Troost J, Albermann N, Emil Haefeli W, Weiss J (2004) Cholesterol modulates P-glycoprotein activity in human peripheral blood mononuclear cells. Biochem Biophys Res Commun 316, 705-711.

[70] Celestino AT, Levy D, Maria Ruiz JL, Bydlowski SP (2015) ABCB1, ABCC1, and LRP gene expressions are altered by LDL, HDL, and serum deprivation in a human doxorubicinresistant uterine sarcoma cell line. Biochem Biophys Res Commun 457, 664-668.

[71] ElAli A, Hermann DM (2012) Liver X receptor activation enhances blood-brain barrier integrity in the ischemic brain and increases the abundance of ATP-binding cassette transporters ABCB1 and ABCC1 on brain capillary cells. Brain Pathol 22, 175-187.

[72] Koldamova R, Lefterov I (2007) Role of LXR and ABCA1 in the pathogenesis of Alzheimer's disease - implications for a new therapeutic approach. Curr Alzheimer Res 4, 171-178.

[73] Cecchelli R, Dehouck B, Descamps L, Fenart L, BueeScherrer VV, Duhem C, Lundquist S, Rentfel M, Torpier G, Dehouck MP (1999) In vitro model for evaluating drug transport across the blood-brain barrier. Adv Drug Deliv Rev 36, 165-178. 